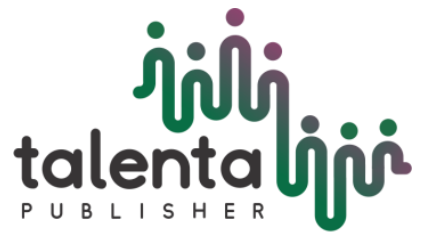

\title{
The Changes of Nutrient Content of Cassava Peel (Manihot esculenta Crantz) That Fermented by Indigenous Microorganisms (IMO) For Animal Feed
}

\author{
Indra Satria Siburian, Edhy Mirwandhono, Yunilas*, Tri Hesty \\ Wahyuni, and Hamdan \\ ${ }^{1}$ Animal Production Study Program, Faculty of Agriculture, Universitas Sumatera Utara, Medan \\ 20155, Indonesia \\ *Email: yunilas11@yahoo.co.id
}

\begin{abstract}
Cassava peel is the waste of processing cassava which is promising enough to be used as alternative animal feed. However, cassava peel has a fairly low nutrient content. Fermentation was one of the way to increase the quality of cassava peel. Fermentation used in this research utilized Indigenous Microorganisms (IMO) with the main substance was the cassava peel itself. This research lasted for 3 months started from December 2018 to February 2019 at the Laboratory of Microbiology and Laboratory of Feed Processing Science and Technology Department of Animal Science Faculty of Agriculture University of Sumatera Utara and Laboratory of Agrichemists and Natural Resources at the Industrial Research and Standardization Office of Medan. This research was designed using Completely Randomized Design (CRD) factorial pattern of $3 \times 3$ with 3 replications, as factor I was the dose of Indigenous Microorganisms (IMO) and factor II was the duration of fermentation. The parameters measured were water content/dry matter, crude fat, crude protein, crude fibre, ash, and Non Nitrogen Free Extract (NNFE) using proximate analysis. The results showed that fermentation of cassava peel using Indigenous Microorganisms (IMO) with the variation of Indigenous Microorganisms (IMO) dose and duration of fermentation give effects, that were increased water content, crude protein, and Non Nitrogen Free Extract (NNFE) and decreased dry ingredient, crude fat, crude fibre, and ash content.
\end{abstract}

Keywords: cassava peel, fermented, indigenous microorganism, crude protein

Received 29 May 2019|Revised 17 June 2019| Accepted 1 August 2019

\section{Introduction}

Utilization of cassava peel waste as one solution to overcome the problem of providing feed

[1]. It is also as an effort to reduce environmental pollution caused [2]. The amount of cassava peel waste in Indonesia is quite abundant because of its huge utilization and its existence is quite good. However, the nutritional content of cassava skin is fairly low, especially crude protein content. 
Various types of processing were carried out on feedstuffs in order to increase the nutrient content and reduce antinutrient substances, one of that was fermentation. Fermentation is the process of breaking down organic compounds into simpler compounds involving the role of microorganisms [3].

\section{Methods}

The research used Completely Randomized Design (CRD) factorial pattern with 2 factors, each factor consisting of 3 levels ( $3 \times 3$ ) with 3 replications, so that 27 research units were obtained.

Factor I: dose of IMO solution (D)

$\mathrm{D}_{1}=1 \%$

$\mathrm{D}_{2}=3 \%$

$\mathrm{D}_{3}=5 \%$

Factor II: duration of fermentation (L)

$\mathrm{L}_{1}=3$ days

$\mathrm{L}_{2}=5$ days

$\mathrm{L}_{3}=7$ days

The replications were got from this formula.

$\mathrm{a} \times \mathrm{b}(\mathrm{r}-1) \geq 15$

$3 \times 3(\mathrm{r}-1) \geq 15$

$9(\mathrm{r}-1) \geq 15$

$9 \mathrm{r}-9 \geq 15$

$9 r \geq 15+9$

$9 \mathrm{r} \geq 24$

$r \geq 24 / 9$

$r \geq 2,6 \approx 3$

The linear equation used is as follows.

$$
\begin{gathered}
Y \mathbf{i j k}=\boldsymbol{\mu}+\boldsymbol{\alpha i}+\boldsymbol{\beta} \mathbf{j}+(\boldsymbol{\alpha} \boldsymbol{\beta}) \mathbf{i j}+\boldsymbol{\varepsilon i j k} \\
\mathrm{i}=1,2, \ldots, \mathrm{a} ; \mathbf{j}=1,2, \ldots, \mathrm{b} ; \mathrm{k}=1,2, \ldots, \mathrm{c}
\end{gathered}
$$

Information:

Yijk = The results of observation for factor A level $\mathrm{i}$, factor $\mathrm{B}$ level $\mathrm{j}$, on the $\mathrm{k}$ replication

$\mu \quad=$ General mean

$\alpha \mathrm{i}=$ Effect of factor $\mathrm{A}$ on the $\mathrm{i}$ level

$\beta \mathrm{j}=$ Effect of factor $\mathrm{B}$ on the $\mathrm{j}$ level

$(\alpha \beta) \mathrm{ij}=$ Interaction between $\mathrm{A}$ and $\mathrm{B}$ at factor $\mathrm{A}$ level $\mathrm{i}$, factor $\mathrm{B}$ level $\mathrm{j}$

eijk = Experimentreplication error for factor A level $\mathrm{i}$, factor $\mathrm{B}$ level $\mathrm{j}$ on the $\mathrm{k}$ 
Table 1. The research design that will be used

\begin{tabular}{ccccc}
\hline Factor I: & $\mathrm{r}$ & \multicolumn{2}{c}{ Factor II: duration of fermentation (L) } \\
\cline { 3 - 5 } dose of IMO (D) & & $\mathrm{L}_{1}(3$ days $)$ & $\mathrm{L}_{2}(5$ days $)$ & $\mathrm{L}_{3}$ (7 days) \\
\hline \multirow{3}{*}{$\mathrm{D}_{1}(1 \%)$} & $\mathrm{U}_{1}$ & $\mathrm{D}_{1} \mathrm{~L}_{1} \mathrm{U}_{1}$ & $\mathrm{D}_{1} \mathrm{~L}_{2} \mathrm{U}_{1}$ & $\mathrm{D}_{1} \mathrm{~L}_{3} \mathrm{U}_{1}$ \\
& $\mathrm{U}_{2}$ & $\mathrm{D}_{1} \mathrm{~L}_{1} \mathrm{U}_{2}$ & $\mathrm{D}_{1} \mathrm{~L}_{2} \mathrm{U}_{2}$ & $\mathrm{D}_{1} \mathrm{~L}_{3} \mathrm{U}_{2}$ \\
& $\mathrm{U}_{3}$ & $\mathrm{D}_{1} \mathrm{~L}_{1} \mathrm{U}_{3}$ & $\mathrm{D}_{1} \mathrm{~L}_{2} \mathrm{U}_{3}$ & $\mathrm{D}_{1} \mathrm{~L}_{3} \mathrm{U}_{3}$ \\
\hline \multirow{2}{*}{$\mathrm{D}_{2}(3 \%)$} & $\mathrm{U}_{1}$ & $\mathrm{D}_{2} \mathrm{~L}_{1} \mathrm{U}_{1}$ & $\mathrm{D}_{2} \mathrm{~L}_{2} \mathrm{U}_{1}$ & $\mathrm{D}_{2} \mathrm{~L}_{3} \mathrm{U}_{1}$ \\
& $\mathrm{U}_{2}$ & $\mathrm{D}_{2} \mathrm{~L}_{1} \mathrm{U}_{2}$ & $\mathrm{D}_{2} \mathrm{~L}_{2} \mathrm{U}_{2}$ & $\mathrm{D}_{2} \mathrm{~L}_{3} \mathrm{U}_{2}$ \\
& $\mathrm{U}_{3}$ & $\mathrm{D}_{2} \mathrm{~L}_{1} \mathrm{U}_{3}$ & $\mathrm{D}_{2} \mathrm{~L}_{2} \mathrm{U}_{3}$ & $\mathrm{D}_{2} \mathrm{~L}_{3} \mathrm{U}_{3}$ \\
\hline \multirow{3}{*}{$\mathrm{D}_{3}(5 \%)$} & $\mathrm{U}_{1}$ & $\mathrm{D}_{3} \mathrm{~L}_{1} \mathrm{U}_{1}$ & $\mathrm{D}_{3} \mathrm{~L}_{2} \mathrm{U}_{1}$ & $\mathrm{D}_{3} \mathrm{~L}_{3} \mathrm{U}_{1}$ \\
& $\mathrm{U}_{2}$ & $\mathrm{D}_{3} \mathrm{~L}_{1} \mathrm{U}_{2}$ & $\mathrm{D}_{3} \mathrm{~L}_{2} \mathrm{U}_{2}$ & $\mathrm{D}_{3} \mathrm{~L}_{3} \mathrm{U}_{2}$ \\
& $\mathrm{U}_{3}$ & $\mathrm{D}_{3} \mathrm{~L}_{1} \mathrm{U}_{3}$ & $\mathrm{D}_{3} \mathrm{~L}_{2} \mathrm{U}_{3}$ & $\mathrm{D}_{3} \mathrm{~L}_{3} \mathrm{U}_{3}$ \\
\hline
\end{tabular}

\subsection{Parameters of Research}

The parameters of the research were moisture content, dry matter content, crude fat content, crude protein content, crude fiber content, ash content, NNFE content, and cyanide acid level.

\section{Moisture Content}

Moisture content $=$ sample weight before drying $\times 100 \%$

sample weight after drying

\section{Dry Matter Content (DM)}

$\mathrm{DM}=100 \%$ - Moisture content

\section{Crude Fat Content (CF)}

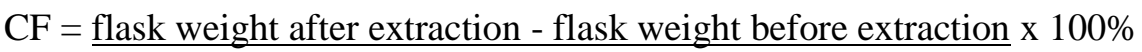
sample weight

\section{Crude Protein Content (CP)}

$\mathrm{CP}=\left(\underline{\mathrm{V}}_{1} \underline{\mathrm{HCl}}=\underline{\mathrm{V}_{2}} \underline{\mathrm{HCl}) \times \mathrm{N} \times 0,014 \times 6,25 \times \text { dilution }}\right.$

factor sample weight

\section{Crude Fiber Content (CF)}

$\mathrm{CF}=\frac{\text { sample weight }- \text { ash weight }}{\text { sediment weight on filter paper }} \times 100 \%$ 


\section{Ash Content}

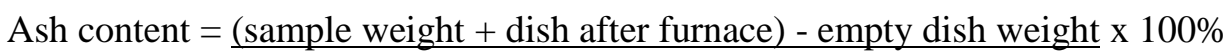
sample before furnace weight

\section{Non Nitrogen Free Extract (NNFE)}

$\mathrm{NNFE}=100 \%-(\%$ moisture $+\% \mathrm{CF}+\% \mathrm{CP}+\% \mathrm{CF}+\%$ ash $)$

\subsection{Conduction of Research}

The research was conducted in two steps, they were the making of Indigenous Microorganisms (IMO) and fermentation of cassava peel.

\subsection{Analysis of Data}

Data obtained and analyzed by Completely Randomized Design (CRD) factorial pattern, if obtained real or very real results then continued with Duncan's mean range test (DMRT).

\section{Results and Analysis}

\subsection{Moisture Content}

Table 2. Moisture content of fermented cassava peel (\%) based on dry matter content

\begin{tabular}{crrrr}
\hline \multirow{2}{*}{ Dose of IMO (D) } & \multicolumn{3}{c}{ Duration of fermentation $(\mathrm{L})$} & \\
\cline { 2 - 4 } & $\mathrm{L}_{1}(3$ days $)$ & $\mathrm{L}_{2}(5$ days $)$ & $\mathrm{L}_{3}(7$ days $)$ & Mean \\
\hline $\mathrm{D}_{1}(1 \%)$ & $6,91^{\mathrm{Aa}}$ & $7,89^{\mathrm{Ab}}$ & $9,49^{\mathrm{Ab}}$ & 8,10 \\
$\mathrm{D}_{2}(3 \%)$ & $7,61^{\mathrm{Aa}}$ & $9,54^{\mathrm{Bb}}$ & $10,60^{\mathrm{Bb}}$ & 9,25 \\
$\mathrm{D}_{3}(5 \%)$ & $7,94^{\mathrm{Ba}}$ & $10,87^{\mathrm{Bb}}$ & $11,33^{\mathrm{Bb}}$ & 10,05 \\
\hline Mean & 7,49 & 9,44 & 10,48 &
\end{tabular}

Information: The different superscripts on the same row and column show significant differences $(\mathrm{P}<$ $0,05)$.

Notation with uppercase letter indicates the dose of IMO, notation with lowercase letter indicates the duration of fermentation.

Based on the results of Duncan's mean range test (DMRT) was known that the interaction between the two factors increased the moisture content, wherein the highest increased of moisture content was $\mathrm{D}_{3} \mathrm{~L}_{3}$ from $6,00 \%$ to $11,33 \%$ or increased in the amount of $47,04 \%$ and the lowest increased was $\mathrm{D}_{1} \mathrm{~L}_{1}$ from $6,00 \%$ to $6,91 \%$ or increased in the amount of $13,17 \%$. However, the $\mathrm{D}_{2} \mathrm{~L}_{2}$ treatment was known as an optimal teatment to increase the moisture content in fermented cassava peel because the value was not significantly different from $\mathrm{D}_{3} \mathrm{~L}_{3}$, which was from $6,00 \%$ to $9,54 \%$ or increased in the amount of $37,11 \%$. 
From the results of the research was found that the higher dose of IMO and the longer the duration of fermentation caused an increased in moisture content. This was presumably because microbes carry out the process of metabolism of carbohydrate from cassava peel during fermentation to be used as an energy source and water was a by-product of this process. This was supported by the results of the research [4].

\subsection{Dry Matter Content}

Table 3. Dry matter content of fermented cassava peel (\%)

\begin{tabular}{crrrr}
\hline \multirow{2}{*}{ Dose of IMO (D) } & \multicolumn{3}{c}{ Duration of fermentation (L) } & \\
\cline { 2 - 4 } & $\mathrm{L}_{1}$ (3 days) & $\mathrm{L}_{2}$ (5 days) & $\mathrm{L}_{3}$ (7 days) & Mean \\
\hline $\mathrm{D}_{1} \quad(1 \%)$ & $93,09^{\mathrm{Aa}}$ & $92,11^{\mathrm{Ab}}$ & $90,51^{\mathrm{Ab}}$ & 91,90 \\
$\mathrm{D}_{2} \quad(3 \%)$ & $92,39^{\mathrm{Aa}}$ & $90,46^{\mathrm{Bb}}$ & $89,40^{\mathrm{Bb}}$ & 90,75 \\
$\mathrm{D}_{3} \quad(5 \%)$ & $92,06^{\mathrm{Aa}}$ & $89,13^{\mathrm{Bb}}$ & $88,67^{\mathrm{Bb}}$ & 89,95 \\
\hline \multicolumn{2}{c}{ Mean } & 92,51 & 90,56 & 89,52 \\
\hline Information: The different superscripts on the same row and column show significant differences (P < \\
0,05).
\end{tabular}

Notation with uppercase letter indicates the dose of IMO, notation with lowercase letter indicates the duration of fermentation.

Based on the results of Duncan's mean range test (DMRT) was known that the interaction between the two factors decreased the dry matter content. The highest decreased of dry matter content was $\mathrm{D}_{3} \mathrm{~L}_{3}$ from $94,00 \%$ to $88,67 \%$ or decreased in the amount of $5,67 \%$ and the lowest decreased in dry matter content in $\mathrm{D}_{1} \mathrm{~L}_{1}$ from $94,00 \%$ to $93,09 \%$ or decreased in the amount of $0,97 \%$. However, the $\mathrm{D}_{2} \mathrm{~L}_{2}$ treatment was found to be not significantly different from $\mathrm{D}_{3} \mathrm{~L}_{3}$, because there was a decreased of dry matter content in fermented cassava peel, from $94,00 \%$ to $90,46 \%$ or decreased in the amount of $3,77 \%$.

The increased of water content was inversely proportional to the decreased in the dry matter content of fermented cassava peel. It was known that the higher dose of IMO and the longer fermentation duration would increased the moisture content of fermented cassava peel, so the dry matter content will be lower. This was according to research [5] whom found that after fermentation, dry matter content became lower. 


\subsection{Crude Fat}

Table 4. Crude fat content of fermented cassava peel (\%) based on dry matter content

\begin{tabular}{ccrrr}
\hline & \multicolumn{3}{c}{ Duration of fermentation (L) } & \multirow{2}{*}{ Mean } \\
\cline { 2 - 4 } Dose of IMO (D) & $\mathrm{L}_{1}$ (3 days) & $\mathrm{L}_{2}$ (5 days) & $\mathrm{L}_{3}$ (7 days) & \\
\hline $\mathrm{D}_{1}(1 \%)$ & $1,16^{\mathrm{Aa}}$ & $1,16^{\mathrm{Aa}}$ & $1,15^{\mathrm{Aa}}$ & 1,16 \\
$\mathrm{D}_{2}(3 \%)$ & $1,12^{\mathrm{Ba}}$ & $1,07^{\mathrm{Bb}}$ & $1,04^{\mathrm{Bb}}$ & 1,08 \\
$\mathrm{D}_{3}(5 \%)$ & $1,11^{\mathrm{Ba}}$ & $1,05^{\mathrm{Bb}}$ & $1,05^{\mathrm{Bb}}$ & 1,07 \\
\hline Mean & 1,13 & 1,09 & 1,08 &
\end{tabular}

Information: The different superscripts on the same row and column show very significant differences $(\mathrm{P}<0,01)$.

Notation with uppercase letter indicates the dose of IMO, notation with lowercase letter indicates the duration of fermentation.

Based on the results of Duncan's mean range test (DMRT) was found that the interaction between the two factors resulted the highest decreased of crude fat content was in $\mathrm{D}_{2} \mathrm{~L}_{3}$ from $1,43 \%$ to $1,04 \%$ or decreased in the amount of $27,27 \%$ and the lowest decreased of crude fat content was in $\mathrm{D}_{1} \mathrm{~L}_{1}$ and $\mathrm{D}_{1} \mathrm{~L}_{2}$ from $1,43 \%$ to $1,16 \%$ or decreased in the amount of $18,88 \%$. However, the treatment of $\mathrm{D}_{2} \mathrm{~L}_{2}$ was known to be optimal treatment in reducing crude fat content in fermented cassava peel because the value was not significantly different from $\mathrm{D}_{2} \mathrm{~L}_{3}$, which was from $1,43 \%$ to $1,07 \%$ or decreased in the amount of $25,17 \%$.

The decreased in crude fat content of cassava peel substrate was thought to be due to microbes produced lipase enzymes which function to degrade fat. The higher used of dose of IMO and the longer duration of the fermentation will increase the mass of microbes that worked to ferment cassava peel. Increased microbial mass, lipase enzymes produced would be higher. This was in accordance with statement [4].

\subsection{Crude Protein}

Table 5. Crude protein content of fermented cassava peel (\%) based on dry matter content

\begin{tabular}{|c|c|c|c|c|}
\hline \multirow[b]{2}{*}{ Dose of IMO (D) } & \multicolumn{3}{|c|}{ Duration of fermentation (L) } & \multirow[b]{2}{*}{ Mean } \\
\hline & $\mathrm{L}_{1}$ (3 days) & $\mathrm{L}_{2}$ (5 days) & $\mathrm{L}_{3}$ (7 days) & \\
\hline $\mathrm{D}_{1}(1 \%)$ & $4,96^{\mathrm{Aa}}$ & $5,13^{\mathrm{Ab}}$ & $4,93^{\mathrm{Ab}}$ & 5,01 \\
\hline $\mathrm{D}_{2} \quad(3 \%)$ & $5,60^{\mathrm{Ba}}$ & $5,35^{\mathrm{Bb}}$ & $5,05^{\mathrm{Bb}}$ & 5,33 \\
\hline $\mathrm{D}_{3} \quad(5 \%)$ & $5,77^{\mathrm{Ba}}$ & $5,74^{\mathrm{Ba}}$ & $5,24^{\mathrm{Bb}}$ & 5,58 \\
\hline Mean & 5,44 & 5,41 & 5,07 & \\
\hline
\end{tabular}


Notation with uppercase letter indicates the dose of IMO, notation with lowercase letter indicates the duration of fermentation.

Based on the results of Duncan's mean range test (DMRT) was found that the interaction between the two factors resulted the highest increased of crude protein content was in $\mathrm{D}_{3} \mathrm{~L}_{1}$ from $4,17 \%$ to $5,77 \%$ or increased in the amount of $27,73 \%$ and the lowest increased of crude protein content occurred in $\mathrm{D}_{1} \mathrm{~L}_{3}$ from $4,17 \%$ to $4,93 \%$ or increased in the amount of $15,42 \%$. However, the treatment of $\mathrm{D}_{2} \mathrm{~L}_{1}$ was known to be optimal treatment to increased crude protein content because the value was not significantly different from $\mathrm{D}_{3} \mathrm{~L}_{1}$, which increased the crude protein content from $4,17 \%$ to $5,60 \%$ or increased in the amount of $25,54 \%$.

From the results of the research also was found that the higher dose of IMO given as fermentation starter of cassava peel, caused an increased of crude protein content. The higher dose of IMO that used in the fermentation caused the mass of microbes that worked on cassava peel fermentation would be increased. Microbes were living organisms where the body's constituent structure was protein, so it can be said that microbes were producers of Single Cell Proteins (SCP). The higher number of microbes that lived on fermented cassava peel, it would be increased the Single Cell Protein (SCP). This was in accordance with statement [4].

In addition, the increased in crude protein content was suspected because microbes that worked in the fermentation process converted inorganic $\mathrm{N}$ in the form of urea found in IMO to organic $\mathrm{N}$ (protein). This was according to the statement [6]. Furthermore, the increased in the protein content of fermented cassava peel by indigenous microorganisms was suspected because indigenous microorganisms contained protelitic microbes which produced protease enzymes that overhaul the protein into polypeptides which then become simple peptides. This was in accordance with research by [7]. The end result of this reshuffle was free amino acids and when analyzed, amino acids are counted as proteins so that crude protein levels increased.

However, the longer fermentation duration did not have positive impact on increasing crude protein content. The highest crude protein content occurred in fermentation on the third day, decreased on the fifth and seventh day. It was suspected that the decreased in crude protein content was due to the fermentation process, microbes degraded proteins into volatile ammonia $\left(\mathrm{NH}_{3}\right)$ compounds. The longer the fermentation time, the more protein was converted to ammonia which then evaporated so that the crude protein content dropped. This is according to research by [8]. 


\subsection{Crude Fiber}

Table 6. Crude fiber content of fermented cassava peel (\%) based on dry matter content

\begin{tabular}{ccccc}
\hline & \multicolumn{3}{c}{ Duration of fermentation (L) } & \multirow{2}{*}{ Mean } \\
\cline { 2 - 4 } Dose of IMO (D) & $\mathrm{L}_{1}$ (3 days) & $\mathrm{L}_{2}$ (5 days) & $\mathrm{L}_{3}$ (7 days) & \\
\hline $\mathrm{D}_{1}(1 \%)$ & $14,81^{\mathrm{Aa}}$ & $13,69^{\mathrm{Ab}}$ & $12,34^{\mathrm{Ab}}$ & 13,61 \\
$\mathrm{D}_{2}(3 \%)$ & $13,62^{\mathrm{Ba}}$ & $12,64^{\mathrm{Bb}}$ & $11,57^{\mathrm{Bb}}$ & 12,61 \\
$\mathrm{D}_{3}(5 \%)$ & $13,36^{\mathrm{Ba}}$ & $11,63^{\mathrm{Bb}}$ & $10,39^{\mathrm{Bb}}$ & 11,80 \\
\hline Mean & 13,93 & 12,65 & 11,43 & \\
\hline
\end{tabular}

Information: The different superscripts on the same row and column show very significant differences $(\mathrm{P}<0,01)$.

Notation with uppercase letter indicates the dose of IMO, notation with lowercase letter indicates the duration of fermentation.

Based on the results of Duncan's mean range test (DMRT) was found an interaction between the two factors that caused the highest decreased in crude fiber content in $\mathrm{D}_{3} \mathrm{~L}_{3}$ from $16,88 \%$ to $10,39 \%$ or decreased in the amount of $38,45 \%$ and the lowest decreased in crude fiber content on $\mathrm{D}_{1} \mathrm{~L}_{1}$ from $16,88 \%$ to $14,81 \%$ or decreased in the amount of $12,26 \%$. However, the $\mathrm{D}_{2} \mathrm{~L}_{2}$ treatment was known to be optimal treatment for reducing crude fiber content because the value was not significantly different from $\mathrm{D}_{3} \mathrm{~L}_{3}$, which was the decreased in crude fiber content from $16,88 \%$ to $12,64 \%$ or decreased in the amount of $25,12 \%$.

From the results of the research, it was known that the higher the dose of IMO used as fermentation starter and the longer the fermentation duration would have a positive effect on the decreased in crude fiber content. This was presumably because in IMO there are cellulolytic microbes that produce cellulase enzymes, in which this enzymes were able to degraded cellulose molecules. Thus, the higher the IMO dose and the longer the duration of fermentation took place, the higher the microbial mass that lived on the substrate, the more cellulase enzymes produced. This was in accordance with research [4].

\subsection{Ash Content}

Table 7. Ash content of fermented cassava peel (\%) based on dry matter content

\begin{tabular}{ccccc}
\hline & \multicolumn{3}{c}{ Duration of fermentation (L) } & \multirow{2}{*}{ Mean } \\
\cline { 2 - 4 } Dose of IMO (D) & $\mathrm{L}_{1}$ (3 days) & $\mathrm{L}_{2}$ (5 days) & $\mathrm{L}_{3}$ (7 days) & \\
\hline $\mathrm{D}_{1}(1 \%)$ & 6,09 & 5,31 & 5,08 & $5,49^{\mathrm{A}}$ \\
$\mathrm{D}_{2}(3 \%)$ & 5,60 & 4,77 & 4,44 & $4,94^{\mathrm{B}}$ \\
$\mathrm{D}_{3}(5 \%)$ & 5,30 & 4,46 & 4,31 & $4,69^{\mathrm{B}}$ \\
\hline Mean & $5,66^{\mathrm{a}}$ & $4,85^{\mathrm{b}}$ & $4,61^{\mathrm{b}}$ & \\
\hline
\end{tabular}


Information: The different superscripts on the different row and column show very significant differences $(\mathrm{P}<0,01)$.

Notation with uppercase letter indicates the dose of IMO, notation with lowercase letter indicates the duration of fermentation.

From the results of the analysis of variance was shown that the IMO dose and fermentation duration had a very significant effect $(\mathrm{P}<0,01)$ on changes in ash content in fermented cassava peel. However, there was no interaction between the two factors. Based on the results of Duncan's mean range test (DMRT), it was found that there was a decreased in ash content of fermented cassava peel. In terms of the dose of IMO used, the highest average decreased in ash content was in $\mathrm{D}_{3}$ from $6,78 \%$ to $4,69 \%$ or decreased in the amount of $30,83 \%$ and the lowest average decreased in ash content in $\mathrm{D}_{1}$ from $6,78 \%$ to $5,49 \%$ or decreased in the amount of $19,03 \%$. However, the used of IMO dose on $\mathrm{D}_{2}$ was known to be optimal treatment because the reducing value was not significantly different from $\mathrm{D}_{3}$, which was from $6,78 \%$ to $4,85 \%$ or decreased in the amount of $28,47 \%$. Meanwhile, when divined from the duration of fermentation, the highest average decreased of the ash content in $\mathrm{L}_{3}$ from $6,78 \%$ to $4,61 \%$ or decreased in the amount of 32,01\% and the lowest average decreased in ash content in $\mathrm{L}_{1}$ from $6,78 \%$ to $5,66 \%$ or decreased in the amount of $16,52 \%$. The $\mathrm{L}_{2}$ treatment has been optimal treatment in reducing the ash content in fermented cassava peel because the average decreased was not significantly different from $\mathrm{L}_{3}$, which was from $6,78 \%$ to $4,94 \%$ or decreased in the amount of $27,14 \%$.

The decreased in ash content was caused by microbial activity that degraded cassava peel resulting the increased in organic matter. The higher the dose of IMO and the longer fermentation duration, the more of microbes mass that worked in the fermentation process increased. Thus microbial worked during the fermentation process was more optimal in degrading cassava peel so that more organic matter were degraded and the ash content decreased. This was in accordance with research by [9] and [10].

The decreased in ash content identified an increased in the content of organic matter substrate. Organic materials contain nutritional substances that are quite important, namely protein, fat, and carbohydrates, and vitamins. Through the fermentation process, the ash content of cassava peel is expected to decrease. 


\subsection{Non Nitrogen Free Extract (NNFE) Content}

Table 8. Non Nitrogen Free Extract (NNFE) content of fermented cassava peel (\%) based on dry matter content

\begin{tabular}{ccccc}
\hline & \multicolumn{3}{c}{ Duration of fermentation (L) } & \multirow{2}{*}{ Mean } \\
\cline { 2 - 4 } Dose of IMO (D) & $\mathrm{L}_{1}$ (3 days) & $\mathrm{L}_{2}$ (5 days) & $\mathrm{L}_{3}$ (7 days) & \\
\hline $\mathrm{D}_{1}(1 \%)$ & 66,07 & 66,82 & 67,00 & $66,63^{\mathrm{A}}$ \\
$\mathrm{D}_{2}(3 \%)$ & 68,43 & 66,63 & 67,27 & $67,45^{\mathrm{A}}$ \\
$\mathrm{D}_{3}(5 \%)$ & 66,52 & 66,25 & 67,68 & $66,81^{\mathrm{A}}$ \\
\hline Mean & $67,01^{\mathrm{a}}$ & $66,57^{\mathrm{a}}$ & $67,32^{\mathrm{a}}$ & \\
\hline
\end{tabular}

Information: The same superscripts on the different row and column show non significant differences $(\mathrm{P}>0,05)$.

Notation with uppercase letter indicates the dose of IMO, notation with lowercase letter indicates the duration of fermentation.

Analysis of variance showed that the treatment of various IMO dose and duration of fermentation had no significant effect $(\mathrm{P}>0,05)$ on NNFE content of fermented cassava peel. Between the two factors also showed no interaction. Based on the results of Duncan's mean range test (DMRT), it was found that there was an increased in NNFE content in terms of IMO dose used, the highest average increased in $\mathrm{D}_{2}$ from $64,74 \%$ to $67,45 \%$ or increased in the amount of 4,02\% and the lowest average increased in NNFE content in $\mathrm{D}_{1}$ from $64,74 \%$ to $66,63 \%$ or increased in the amount of $2,84 \%$. The $\mathrm{D}_{1}$ treatment was known as optimal treatment that increased NNFE content because the average value of the increased was not significantly different from $\mathrm{D}_{2}$, which was from $64,74 \%$ to $66,63 \%$ or increased in the amount of $2,84 \%$. Meanwhile, from the duration of fermentation, the average increased in NNFE content was highest in $\mathrm{L}_{3}$ from $64,74 \%$ to $67,32 \%$ or $3,83 \%$ and the average increased in NNFE content was the lowest at $\mathrm{L}_{2}$ from $64,74 \%$ to $66,57 \%$ or increased in the amount of 2,75 $\%$. However, $\mathrm{L}_{1}$ treatment was known to have optimally increased NNFE content because the average value of the increased was not significantly different from $\mathrm{L}_{3}$, which was from $64,74 \%$ to $67,01 \%$ or increased in the amount of $3,39 \%$.

Based on the results of the research, it was known that the use of MOL doses with a level of 3 $\%$ and duration of fermentation was 5 days will increase NNFE content in cassava peel. This dose of IMO and duration of fermentation provided the opportunity for microbes to grow optimally on the substrate. Thus, the microbial mass act in the process of changing organic matter on cassava peel was increasing. As was known, the more organic matter was degraded in the fermentation process, the lower the ash content would be. The impact of this was an increased in NNFE content. This was supported by the results of the study by [11]. 


\subsection{Recapitulation of Research Data}

Table 9. The effect of dose of IMO and duration of fermentation on the nutrient content of fermented cassava peel

\begin{tabular}{cccccccc}
\hline Treatments & $\begin{array}{c}\text { Moisture } \\
\text { content } \\
(\%)\end{array}$ & $\begin{array}{c}\text { Dry } \\
\text { matter } \\
(\%)\end{array}$ & $\begin{array}{c}\text { Crude } \\
\text { fat } \\
(\%)\end{array}$ & $\begin{array}{c}\text { Crude } \\
\text { protein } \\
(\%)\end{array}$ & $\begin{array}{c}\text { Crude } \\
\text { fiber } \\
(\%)\end{array}$ & $\begin{array}{c}\text { Ash } \\
(\%)\end{array}$ & $\begin{array}{c}\text { NNFE } \\
(\%)\end{array}$ \\
\hline $\mathrm{D}_{1} \mathrm{~L}_{1}$ & 6,91 & 93,09 & 1,16 & 4,96 & 14,81 & 6,09 & 66,07 \\
$\mathrm{D}_{1} \mathrm{~L}_{2}$ & 7,89 & 92,11 & 1,16 & 5,13 & 13,69 & 5,31 & 66,82 \\
$\mathrm{D}_{1} \mathrm{~L}_{3}$ & 9,49 & 90,51 & 1,15 & 4,93 & 12,34 & 5,08 & 67,00 \\
\hline $\mathrm{D}_{2} \mathrm{~L}_{1}$ & 7,61 & 92,39 & 1,12 & 5,60 & 13,62 & 5,60 & 68,43 \\
$\mathrm{D}_{2} \mathrm{~L}_{2}$ & 9,54 & 90,46 & 1,07 & 5,35 & 12,64 & 4,77 & 66,63 \\
$\mathrm{D}_{2} \mathrm{~L}_{3}$ & 10,60 & 89,40 & 1,04 & 5,05 & 11,57 & 4,44 & 67,27 \\
\hline $\mathrm{D}_{3} \mathrm{~L}_{1}$ & 7,94 & 92,06 & 1,11 & 5,77 & 13,36 & 5,30 & 66,52 \\
$\mathrm{D}_{3} \mathrm{~L}_{2}$ & 10,87 & 89,13 & 1,05 & 5,74 & 11,63 & 4,46 & 66,25 \\
$\mathrm{D}_{3} \mathrm{~L}_{3}$ & 11,33 & 88,67 & 1,05 & 5,24 & 10,39 & 4,31 & 67,68 \\
\hline
\end{tabular}

\section{Conclusion}

Based on the results of the research, it was found that from the three levels of Indigenous Microorganisms (IMO) used and from three levels of fermentation duration, the dose of MOL 3\% $\left(\mathrm{D}_{2}\right)$ and 5-day fermentation $\left(\mathrm{L}_{2}\right)$ was optimal and efficient treatment for increased water content, crude protein, and Non Nitrogen Free Extract (NNFE) and can reduced crude fat, crude fiber, and ash content in cassava peel.

\section{References}

[1] Akhadiarto, S. 2010. Pengaruh Pemanfaatan Limbah Kulit Singkong Dalam Pembuatan Pelet Ransum Unggas. J. Tek. Ling., Vol. 11, No. 1, Hal. 127 - 138.

[2] N Ginting.2018. Comparison of isolate dadih with yeast dadih in improving nutrition quality of Cassava Waste (CW). IOP Conf Series: Earth and Env Science 141 (2018) 012008

[3] Pamungkas, W. 2011. Teknologi Fermentasi, Alternatif Solusi Dalam Upaya Pemanfaatan Bahan Pakan Lokal. Jurnal Media Akuakultur, Vol. 6, No. 1. 
[4] Akbar, C. A., Sukanto, dan S. Rukayah. 2014. Kualitas Pakan Fermentatif Berbahan Kulit Ubi Kayu Dengan Inokulan MEP+ Untuk Kultur Ikan Nila Gesit (Oreochromis niloticus L.). Scripta Biologica, Vol. 1, No. 2.

[5] Harahap, H. L., Yunilas, N. Ginting, E. Mirwandhono, and A. H. Daulay. 2018. Utilization of Pliek U Bacteria (YNH11 Isolates) in Fermenting Process of Coconut Dregs (Cocos Nucifera L.) Jurnal Peternakan Integratif. Vol. 6 No. 2 (2018).

[6] Wibawa A. A. P., Wirawan I. W., dan Partama I. B. G. 2014. Peningkatan Nilai Nutrisi Dedak Padi Sebagai Pakan Itik Melalui Biofermentasi Dengan Khamir. Denpasar: Program Studi Peternakan, Fakultas Peternakan, Universitas Udayana.

[7] Setiawan, B. 2017. Kandungan Protein Kasar dan Serat Kasar Dedak Padi yang Difermentasi Dengan Mikroorganisme Lokal. Skripsi. Makassar: Fakultas Peternakan Universitas Hasanuddin.

[8] Andarti, I. Y. dan A. K. Wardani. 2015. Pengaruh Lama Fermentasi Terhadap Karakteristik Kimia, Mikrobiologi, dan Organoleptik Miso Kedelai Hitam (Glycine max (L)). Jurnal Pangan dan Agroindustri. Vol. 3 No. 3 p. 889 - 898, Juli 2015.

[9] Styawati, N. E., Muhtarudin, dan Liman. 2013. Pengaruh Lama Fermentasi Trametes sp. Terhadap Kadar Bahan Kering, Kadar Abu, dan Kadar Serat Kasar Daun Nenas Varietas Smooth cayene. Lampung: Departemen Peternakan Fakultas Pertanian Universitas Lampung.

[10] Samadi, S. Wajizah, dan Sabda. 2015. Peningkatan Kualitas Ampas Tebu Sebagai Pakan Ternak Melalui Fermentasi Dengan Penambahan Level Tepung Sagu yang Berbeda. Jurnal Agripet. Volume 15 Nomor 2, 2015: 104 - 111.

[11] Kusumaningrum, M., C. I. Sutrisno, dan B. W. H. E. Prasetiyono. 2012. Kualitas Kimia Ransum Sapi Potong Berbasis Limbah Pertanian dan Hasil Samping Pertanian yang Difermentasi Dengan Aspergillus niger. Animal Agriculture Journal, Volume 1 Nomor 2, Hal. 109 - 119. 